\title{
PENERAPAN SISTEM SANITASI KEKERANGAN PADA KELOMPOK USAHA BERSAMA (KUB) NELAYAN KERANG DI DESA BANJAR KEMUNING, KECAMATAN SEDATI, KABUPATEN SIDOARJO
}

\section{(APPLICATION OF VIOLENCE SANITATION SYSTEM IN JOINT VENTURES GROUP (KUB) FISHERIES IN BANJAR KEMUNING SEDATI SIDOARJO)}

\author{
Eka Saputra ${ }^{1}$, Pulung Siswantara ${ }^{2}$ \\ ${ }^{1}$ Departemen Teknologi Hasil Pertanian Fakultas Perikanan dan Kelautan Universitas \\ Airlangga, ${ }^{2}$ Departemen Kesehatan Masyarakat Fakultas Kesehatan Masyarkat \\ Universitas Airlangga \\ e-mail: ekasaputra@fpk.unair.ac.id
}

\begin{abstract}
One way to provide a sense of security to consumers related to consumption of lightness is to eliminate or reduce some of the hazardous substances from the biological, chemical or physical hazards sector. A good approach to ensuring food security, especially shellfish products, is in the process where the shellfish grows or where the shells are taken, especially related to the location where the shellfish lives in areas where there are no sources of pollution, but this is very unlikely because of its live shellfish quite minimal. Warfare taken from the waters should be carried out a good handling process related to sanitation, because the shellfish caught in nature there is a risk of bacterial contaminants and some heavy metals that are harmful to human health. According to the Decree of the Minister of Fisheries and Marine Affairs No. 17 of 2004 that commodity commodities must apply sanitation processes to ensure food security for consumers. The target of business actors in the implementation of this depuration method is the Joint Business Group with BATARI and SARI LAUT shellfish fishermen in Banjar Kemuning village, Sedati District, Sidoarjo Regency. These two groups of fishermen are business actors in catching shells in the form of life before going through the processing process. These two groups have some similarities related to the shellfish they get, generally they get blood clams, batik shells, manuk shells and baling shells.
\end{abstract}

Keywords: food security, sanitation, shellfish

\begin{abstract}
abstrak
Salah satu cara untuk memberikan rasa aman kepada konsumen terkait dengan konsumsi kekerangan adalah mengeliminasi atau mengurang beberapa bahan berbahaya baik itu dari sektor biologi, kimia ataupun bahaya fisik. Pendekatan yang baik dalam menjamin keamanan pangan terutama produk kerang adalah pada proses dimana kerang itu tumbuh atau dimana kerang itu diambil, terutama terkait dengan lokasi dimana kerang hidup pada daerah yang tidak ada sumber pencemarnya, namun hal tersebut sangatlah tidak mungkin karena kerang hidupnya pada kondisi yang cukup minim. Kekerangan yang diambil dari perairan sebaiknya dilakukan proses penanganan yang baik terkait sanitasinya, karena kerang yang tertangkap di alam terdapat resiko kontaminan bakteri dan beberapa logam berat yang berbahaya bagi kesehatan manusia. Menurut Keputusan Menteri Perikanan dan Kelautan No. 17 tahun 2004 bahwa komoditas kekerangan wajib menerapkan proses sanitasi guna menjamin keamanan pangan pada konsumen. Target pelaku usaha dalam kegiatan penerapan metode depurasi ini adalah Kelompok Usaha Bersama nelayan kerang BATARI dan SARI LAUT di desa Banjar Kemuning, Kecamatan Sedati, Kabupaten Sidoarjo. Kedua kelompok nelayan ini merupakan pelaku usaha dalam penangkapan kerang dalam bentuk hidup sebelum melalui proses
\end{abstract}


pengolahan. Kedua kelompok ini memiliki beberapa kesamaan terkait dengan hasil kerang yang mereka dapatkan, umumnya mereka mendapatkan kerang darah, kerang batik, kerang manuk dan kerang baling.

Kata kunci: keamanan, kerang, pangan, sanitasi

\section{PENDAHULUAN}

Kerang merupakan salah satu komoditas perikanan tangkap yang memiliki nilai ekonomis penting. Menurut data statistik Kementrian Kelautan dan Perikanan Tahun 2012 produksi kerang-kerangan (Kerang Darah, Kerang Bulu, Kerang Hijau, Kerang Mutiara, Simping, Tiram dan Remis) di Indonesia mencapai 50.460 ton, sedangkan menurut data statistik Dinas Perikanan dan Kelautan Kabupaten Sidoarjo Tahun 2015, produksi kerang di Sidoarjo mencapai 2.285,3 ton.

Selain komoditas perikanan dari sektor budidaya bandeng dan udang, Kabupaten Sidoarjo juga memiliki keunggulan komoditas perikanan lainnya, yaitu kekerang. Daya tarik masyarakat dalam mengkonsumsi kerang bulu dipicu oleh kandungan gizinya yang tinggi. Kerang mengandung mineral (antara lain kalsium, fosfor, besi, yodium), thiamin, riboflavin, niasin, asam panthothenat, pyridoxine biotin, dan B12 (Departemen Kelautan dan Perikanan, 2006). Kerang memiliki kandungan protein, asam amino, asam lemak, dan vitamin Salah satu kandungan gizi yang khas pada hasil laut adalah asam lemak. Asam lemak tak jenuh (EPA dan DHA) yang terkandung pada berbagai jenis kerang tergolong tinggi. Kerang mengandung EPA 0,124 mg/100 g dan DHA 0,169 mg/100 g lebih tinggi lima kali lipat dibandingkan dengan udang (Imre dan Sahgk, 1997).

Jenis kerang yang ditangkap oleh nelayan kerang di Desa Banjar Kemuning dan Desa Gisik Cemandi adalah kerang darah (Anadara sp.) atau masyarakat sekitar biasanya menyebut kerang kukur dan kerang bulu. Selain jenis kerang tersebut, terdapat pula jenis kerang batik (Paphia undulata), kerang kampak (Atrina sp.) serta jenis siput laut yang biasa disebut keong macan (Babylonia spirata).

Desa Banjar Kemuning terdapat 4 Kelompok Usaha Bersama (KUB) yang bergerak dibidang penangkapan kerang. Rata-rata produksi kerang yang dihasilkan oleh nelayan adalah $100 \mathrm{~kg} /$ hari dengan komposisi hasil tangkapan kerang yang bervariasi. Saat ini terdapat 2 KUB yaitu Bahari dan Lestari (BATARI) dan Sari Laut yang mendapatkan pemesanan kerang dari Fish ' $n$ Blues rekanan World Wild Foundation (WWF) untuk dikirim ke Jakarta mulai tahun 2015. Proses pemesanan yang dilakukan oleh rekanan bersifat fleksibel, sehingga tidak dapat diharapkan keberlanjutannya. Permasalahan yang dihadapi dalam proses penanganan kerang mulai dari pasca penangkapan sampai pengiriman. Selain itu, minimnya pengetahuan KUB dalam melakukan diversifikasi olahan produk kekerangan.

Permasalahan yang dihadapi oleh KUB nelayan kerang adalah kurangnya informasi tentang cara penanganan kerang yang baik. Berdasarkan keputusan Menteri Kelautan dan Perikanan nomor: KEP.17/MEN/2004 tentang Sistem Sanitasi Kekerangan, di dalam keputusan tersebut dijelaskan bagaimana proses penangkapan kerang dari lokasi penangkapan sampai ke proses pengiriman kerang untuk sampai ke tangan konsumen. 
Akan tetapi, saat ini masyarakat kurang mengetahui prosedur yang sudah ditetapkan oleh pemerintah. Salah satu syarat dalam sanitasi kekerangan adalah kandungan mikroorganisme pencemar yakni E. Coli dan juga beberapa logam berat misalnya timbal $(\mathrm{Pb})$ Merkuri $(\mathrm{Hg})$ dan Cadmium $(\mathrm{Cd})$ harus dibawah ambang batas yang sudah ditetapkan. Sebetulnya beberapa pencemar ini dapat direduksi dengan cara melakukan metode depurasi atau purifikasi setelah proses penangkapan. Dari hasil pengamatan tersebut maka dapat dirumuskan permasalahan sebagai berikut : 1) Nelayan kerang masih belum mengetahui informasi tentang cara melakukan penanganan pasca tangkap sehingga berakibat pada kemunduran mutu; 2) Kurangnya informasi tentang sistem sanitasi kekerangan dan juga diversifikasi produk hasil tangkap.

Dalam menangani permasalahan mitra yang dilakukan oleh pengusul adalah melakukan pelatihan secara komprehensif dalam penanganan kerang dari proses penangkapan sampai kedalam proses pasca tangkap sesuai dengan syarat yang sudah ditentukan oleh keputusan Menteri terkait sanitasi kekerangan. Selain itu, untuk meningkatkan pendapatan usaha pada KUB, dilakukan pelatihan pengolahan hasil perikanan dengan memberikan pelatihan dalam diversifikasi olahan produk perikanan mulai dari kerang krispi, abon, kerupuk dan lainnya.

\section{METODE PENGABDIAN MASYARAKAT}

Dalam pelaksanaan Program Kemitraan Masyarakat pada Kelompok Usaha Bersama Nelayan Kerang adalah dengan melakukan 3 solusi kegiatan dalam penanganan kerang pasca panen yaitu:

\section{Penanganan Bahan Baku}

Dalam penanganan bahan baku kerang pasca penangkapan dilakukan dengan memberikan pelatihan dalam pencucian kerang dan proses purifikasi (depurasi) kerang. Depurasi adalah proses pemeliharaan kerang didalam kondisi yang terkontrol sehingga kontaminan mikroorganisme dapat di minimalisir. Proses depurasi ini membutuhkan waktu minimal 44 jam.

\section{Pengolahan Kerang}

Kerang yang sudah dilakukan proses depurasi, dilakukan pengolahan. Umumnya pengolahan yang dilakukan adalah melalui perebusan. Dalam perebusan factor utama yang harus diterapkan adalah Sanitasi dan Higiene, sehingga hasil akhir produk bisa terjamin keamanannya. Untuk kerang dalam bentuk utuh dengan cangkan, langsung dilakukan proses pengemasan. Produk olahan kerang lainnya juga diterapkan pada kegiatan ini, sehingga KUB akan memiliki pengalaman dalam proses diversifikasi olahan produk kerang.

\section{Pengemasan Produk Kerang}

Untuk kerang olahan, proses pengemasan dilakukan dengan metode vacuum sehingga daya awet kerang olahan lebih lama. Sedangkan kerang utuh, dilakukan dengan transportasi tertutup menggunakan es batu sebagai bahan transportasi. 
Metode pendekatan yang akan dilakukan dalam Program PKM ini adalah memberikan wawasan, ilmu pengetahuan dan teknologi tepat guna yang sederhana dan mudah untuk diaplikasikan serta dikembangkan kepada 2 Kelompok Usaha Bersama di Sidoarjo. Teknologi yang ingin ditawarkan untuk mengatasi masalah penanganan bahan baku pasca panen kerang, pengolahan kerang dan pengemasan produk kerang.

Tim pelaksana telah mengaplikasikan penggunaan sistem tersebut dan hasilnya sangat memuaskan. Hal ini tentu sangat tepat dan memberikan manfaat besar apabila diterapkan untuk usaha perikanan kerang di Sidoarjo untuk memeberikan jaminan produk yang aman bagi masyarakat. Tujuan yang ingin dicapai dalam kegiatan ini adalah agar nantinya hasil tangkapan kerang memenuhi Standar Nasional Indonesia (SNI). Program PKM ini akan dilaksanakan pada KUB di nelayan kerang desa Banjar Kemuning di wilayah pesisir Sidoarjo. Harapan selanjutnya adalah menjadikan mitra Program PKM ini dapat dijadikan sebagai percontohan dan mensosialisasikan program ini lebih lanjut kepada masyarakat sekitarnya dan KUB nelayan kerang lainnya. Sarana tempat penyuluhan dan pelatihan serta demoplot untuk kaji terap Program PKM ini telah tersedia. Pelaksanaan kegiatan akan dilakukan secara bertahap, meliputi: 1) Penyuluhan melalui tatap muka dan diskusi; 2) Pelatihan teknologi depurasi; 3) Demoplot kaji terap teknologi depurasi; 4) Bimbingan teknis penanganan pasca tangkap kerang; 5) Pelatihan pengolahan kerang; 6) Pelatihan pengemasan; 7) Monitoring dan evaluasi kegiatan.

Upaya khusus yang dilakukan setelah program ini selesai adalah seberapa jauh program ini mampu disosialisasikan, dikembangkan dan dimanfaatkan oleh masyarakat. Di masa mendatang, diharapkan adanya kerjasama yang sinergis dan berkesinambungan antara Perguruan Tinggi pelaksana program dengan pemerintah daerah atau dinas terkait maupun masyarakat. Partisipasi dari 2 KUB nelayan kerang yang terletak di wilayah pesisir Sidoarjo selaku mitra pada Program PKM ini adalah melalui penyediaan sarana dan prasarana kegiatan selama Program PKM dilaksanakan. Program ini juga didukung oleh pihak desa Banjar Kemuning, Kecamatan Sedati, Kabupaten Sidoarjo.

\section{HASIL DAN PEMBAHASAN}

Hasil yang sudah dicapai dalam pengabdian Program Kemitraan Masyarakat (PKM) adalah:

Kegiatan koordinasi dan survey dengan kelompok usaha bersama (KUB) nelayan kerang di desa banjar kemuning, kecamatan sedati, kabupaten sidoarjo, dimana melalui survey ini maka tim memperoleh data dan masalah kekerangan yang terdapat pada nelayan pengolah kerrang banjar kemuning. Dengan adanya survey ini maka diharapkan kegiatan selanjutnya akan berjalan dengan lancer dan tepat sasaran sehingga diperoleh hasil yang maksimal bagi nelayan pengolah banjar kemuning.

Penyerahan alat kepada kelompok usaha bersama (KUB) nelayan kerang di desa banjar kemuning, kecamatan sedati, kabupaten sidoarjo diwakili oleh Bu Nuryati. Penyerahan dilakukan setelah serangkaian kegiatan kemitraan. Pertama, diskusi dengan mitra terkait keamanan penggunaan alat yang telah terpenuhi dengan penambahan tinggi tempat 
pengeluaran uap alat. Kedua, melalui pengenalan alat ke mitra sebanyak 2 kali untuk memastikan alat dapat digunakan dengan baik dan benar.

Komitmen kemitraan terbagi dua, yaitu mitra dengan tim dan tim dengan mitra. Pertama mitra dengan tim yaitu mitra telah mengunakan alat STEAM kerang dalam proses pengolahan kerang. Melalui penggunaan alat ini mitra telah berhasil melakukan pengiriman kerrang kepada pasar nasional yang salah satunya adalah Fish n' Blues yang sebelumnya sempat terhenti dikarenakan pembaruan standardisasi proses perebusan dan pengupasan pada pengolahan kerang. Fish n' Blues adalah perusahaan pemasok produk perikanan dan kelautan dari nelayan kecil di Indonesia dengan tujuan peningkatan mutu produk nelayan kecil guna peningkatan produktivitas nelayan melalui kerjasama dengan World Wide Fund for Nature-Indonesia (WWF-Indonesia). Berikut adalah bukti pengiriman produk kerang ke pihak Fish n' Blues.

Peningkatan kualitas kerang dapat dilihat berdasarkan perbedaan kenampakan daging kerang. Secara penampaan, produk kerang olahan dengan alat STEAM berwarna oranye cerah dan bersih sedangkan dari hasil konvensional daging bewarna agak pucat, kotor oleh lumpur, dan ukurannya menyusut. Perbedaan kenampakan tersebut dapat dijadikan indikator bahwa kerang hasil STEAM telah mengalami perbaikan kualitas sanitasi dan higiene dari kerang hasil konvensional. Hal itu didasarkan dari pengujian yang telah dilakukan sebelum alat tiba di mitra.

\section{PENUTUP}

Kegiatan pengabdian Program Kemitraan Masyarakat (Pkm) sudah dilakukan berupa pemberian pendampingan bagaimana penerapan sanitasi kekerangan pada kelompok nelayan kerang desa banjar kemuning, selain itu tim pengabdi juga telah memberikan bantuan alat guna menunjang peningkatan kualitas kerang olahan yang dihasilkan. Dengan adanya program pemberdayaan masyarakat melalui penerapan system sanitasi di UKM tersebut, diharapkan mampu meningkatkan nilai tambah dan keberlanjutan usahanya.

\section{DAFTAR PUSTAKA}

Gosling, E. 2003. Bivalve Mollusc. Blackwell Publishing Inc. London

Imre S, Saghk S. 1997. "Fatty acid composition and cholesterol content of mussel and shrimp consumed in Turkey". Journal of Marine Sciences 03 (03): 179-189.

Lawrence, J. Henry L., Hajime T., Philipp, H., Karunasagar, I. And Lahsen, A. 2011. Assesment and Management of Biotoxin Risks in Bivalve Molluscs. Roma: Food and Agriculture Organization

Lee, R., A. Lovatelli and L. Ababouch. 2008. Bivalve Depuration : Fundamental and Practical Aspects. Roma: Food and Agriculture Organization. 